\title{
EXPERIMENTS BASED OF TWO STAY TWO STRAY MODEL APPLICATION TO IMPROVE LEARNING OUTCOMES WATER CYCLE OF STUDENT ELEMENTARY SCHOOL
}

\section{Dwi Nurpalupi Retnosari, Suharno, Peduk Rintayati}

Universitas Sebelas Maret

dwinurpalupixiia5@gmail.com

\section{Article History}

accepted 09/07/2018

approved 01/08/2018

published 17/09/2018

\section{Keywords}

two stay two stray, experiments, learning outcomes, water cycle

\begin{abstract}
The teacher have responsibility to encourage the development of quality learning outcomes in students. The purpose of this research is to improve learning outcomes water cycle by applying experiments based of two stay two stray model in fifth grade elementary school. The type of this research is classroom action research held in three cycles. The subject of this research is fifth grade elementary school amounting to 25 students, researchers and the teacher in that class. The data were collected by interview, observation, test, and document review. Data validity is tested by content validity, triangulation of source and technique. The data analysis used descriptive comparative technique and interactive analysis model Miles Huberman. The conclusion of this research is experiments based of two stay two stray model can improve the learning outcomes water cycle.
\end{abstract}

Social, Humanities, and Education Studies (SHEs): Conference Series https://jurnal.uns.ac.id/shes

p-ISSN 2620-9284

e-ISSN 2620-9292 


\section{PENDAHULUAN}

IPA berhubungan dengan cara mencari tahu tentang alam secara sistematis sehingga IPA bukan hanya penguasaan kumpulan pengetahuan yang berupa fakta, konsep, atau prinsip saja tetapi juga merupakan suatu proses penemuan (Agustiana \& Tika, 2013). Ilmu Pengetahuan Alam adalah ilmu yang mempelajari alam dengan segala isinya, atau secara sederhana merupakan suatu kumpulan pengetahuan yang tersusun secara sistematis tentang gejala alam (Sukardjo, dkk., 2012). IPA merupakan mata pelajaran yang membutuhkan proses pembelajaran yang berkualitas. Proses pembelajaran sangat menentukan bagaimana hasil belajar yang akan didapatkan. Jika proses pembelajaran mengalami masalah atau kurang efektif maka hasil belajar juga tidak akan maksimal dan akan menimbulkan masalah, ditandai dengan rendahnya hasil belajar siswa. Taurina (2015), berpendapat bahwa hasil belajar digambarkan sebagai pernyataan tertulis dari apa yang diharapkan untuk mengetahui, memahami dan dapat melakukan pada akhir masa belajar. Aziz, et al. (2012) berpendapat bahwa guru harus bertanggung jawab untuk mendorong pengembangan hasil belajar yang berkualitas pada siswa, seperti pendekatan mendalam untuk belajar, pemahaman, belajar mandiri, berpikir kritis dan kreatif, pemecahan masalah dan lain-lain. Daur air adalah sistem yang kompleks yang melibatkan sumber air, penggunaan, persediaan dan konsumsi (Zhang et al, 2017). Daur air merupakan komponen yang paling aktif dan paling penting dalam sirkulasi massa global dan energi dalam sistem bumi. Selanjutnya, parameter siklus air seperti penguapan, curah hujan, presipitasi, dan uap air memainkan peran utama dalam perubahan iklim global (Tameemi \& Chuckin, 2016).

Bersumber pada observasi langsung pada tanggal 7 Februari 2018, didapatkan hasil belajar ranah psikomotorik dari lima indikator yaitu: 1) Aktivitas melihat dalam proses pembelajaran daur air, dari 25 siswa didapatkan rata-rata nilai 1, 20, masuk dalam kriteria nilai "Cukup"; 2) Aktivitas berbicara dalam proses pembelajaran daur air, dari 25 siswa didapatkan rata-rata nilai 1, 00, masuk dalam kriteria nilai "Rendah"; 3) Aktivitas mendengarkan dalam proses pembelajaran daur air, dari 25 siswa didapatkan rata-rata nilai 1,00, masuk dalam kriteria nilai "Rendah"; 4) Aktivitas menulis dalam proses pembelajaran daur air, dari 25 siswa didapatkan rata-rata nilai 1, 00, masuk dalam kriteria nilai "Rendah", dan; 5) Mengerjakan tugas dalam proses pembelajaran daur air, dari 25 siswa didapatkan rata-rata nilai 1, 00, masuk dalam kriteria nilai "Rendah". Pada hasil belajar ranah kognitif dari tiga indikator di buat 10 soal yang diberikan kepada 25 siswa, yaitu sebagai berikut: 1) Menjelaskan pengertian daur air, 25 siswa dapat menjelaskan pengertian daur air yang terdapat pada soal nomor 1 dan 2, siswa dengan benar semuanya; 2) Menganalisis tahap-tahap proses daur air, 25 siswa yang menjawab soal nomor 3 benar semua, yang menjawab benar soal nomor 4 hanya 2 siswa, yang menjawab benar soal nomor 5 terdapat 22 siswa, yang menjawab benar soal nomor 6 hanya 7 siswa, yang menjawab benar soal nomor 8 hanya 9 siswa, dan yang menjawab benar soal nomor 9 hanya 14 siswa, setengah lebih dari 25 siswa belum dapat menganalisis tahap-tahap proses daur air dan; 3) Menyusun proses daur air, yang menjawab benar soal nomor 7 hanya 9 siswa, dan yang menjawab benar soal nomor 10 hanya 8 siswa, setengah lebih dari 25 siswa belum dapat menyusun proses daur air. Nilai pretest dari 25 siswa, hanya 8 siswa atau $32 \%$ yang nilainya mencapai $\mathrm{KKM}$, dan 17 siswa atau 68\% mendapat nilai di bawah KKM. Hasil belajar ranah afektif dari 6 indikator yaitu: 1) Penerimaan peserta didik selama pembelajaran daur air, dari 25 siswa didapatkan rata-rata nilai 1, 24, masuk dalam kriteria nilai "Cukup"; 2) Respon peserta didik selama pembelajaran daur air, dari 25 siswa didapatkan rata-rata nilai 1, 00, masuk dalam kriteria nilai "Rendah"; 3) Keaktifan peserta selama pembelajaran daur air, dari 25 siswa didapatkan rata-rata nilai 1, 00, masuk dalam kriteria nilai "Rendah"; 4) Tanggung jawab peserta selama pembelajaran daur air, dari 
25 siswa didapatkan rata-rata nilai 1, 00, masuk dalam kriteria nilai "Rendah"; 5) Kerjasama dengan teman selama pembelajaran daur air, dari 25 siswa didapatkan rata-rata nilai 1, 00, masuk dalam kriteria nilai "Rendah", dan; 6) Keberanian dalam pembelajaran daur air, dari 25 siswa didapatkan rata-rata nilai 1, 00, masuk dalam kriteria nilai "Rendah". Berdasarkan hasil tersebut, perlu diadakan perbaikan untuk meningkatkan kualitas pembelajaran, supaya pembelajaran dapat berjalan dengan efektif dan efisien. Dalam mengatasi rendahnya hasil belajar siswa kelas V SDN Tegalrejo No. 98 Surakarta pada pembelajaran IPA materi daur air, peneliti menggunakan model pembelajaran two stay two stray atau dua tinggal dua tamu berbasis eksperimen.

"Two stay two stray atau dua tinggal dua tamu adalah pembelajaran kelompok dengan tujuan agar siswa dapat saling bekerjasama, bertanggung jawab, saling membantu memecahkan masalah, dan saling mendorong satu sama lain untuk berprestasi" (Huda, 2014). Menurut Aqib (2015) langkah two stay two stray yaitu: a) Siswa bekerjasama dalam kelompok berempat seperti biasa; b) Setelah selesai, dua orang dari masing-masing bertamu kedua kelompok yang lain; c) Dua orang yang tinggal dalam kelompok bertugas membagikan hasil kerja dan informasi mereka ke tamu mereka; d) Tamu mohon diri dan kembali ke kelompok mereka sendiri dan melaporkan temuan mereka dari kelompok lain; e) Kelompok mencocokkan dan membahas hasil kerja mereka."Eksperimen atau percobaan pada pembelajaran IPA merupakan bentuk sederhana dari aspek sains sebagai proses yaitu melakukan kegiatan ilmiah sehingga membangkitkan motivasi siswa menjadi seorang ilmuan di masa akan datang" (Tursinawati, 2013). Dengan menerapkan pembelajaran dengan penemuan dalam pelajaran "anak-anak sekolah masuk ke dalam situasi untuk menemukan kebenaran, membangun aktivitas mereka sendiri dengan elaborasi pengetahuan" (Gabriela \& Petruta, 2015). Menurut Kurniasih \& Sani, (2015) langkah pelaksanaan eksperimen yaitu: a) Menerangkan tujuan pembelajaran yang akan dipelajari; b) Kemudian guru menerangkan tentang model pembelajaran yang akan dilaksanakan; c) Membicarakan terlebih dahulu permasalahan yang seknifikasi untuk diangkat dan akan dipertontonkan; d) Sebelum guru menetapkan alat yang diperlukan langkah-langkah apa saja yang harus di variabel-variabel apa yang harus dikontrol; e) Setelah eksperimen dilakukan guru harus mengumpulkan laporan, proses kegiatan, dan mengadakan tes untuk menguji pemahaman murid. Two stay two stray dibuat dengan berbasis eksperimen karena eksperimen dapat membuktikan kebenaran suatu teori dengan kuat, terutama IPA materi daur air. Dengan berbasis eksperimen siswa dapat belajar melalui berbuat dan dapat melihat kenyataan yang asli dari suatu teori dalam materi pembelajaran, dan dapat melihat bukti yang kuat sehingga siswa dapat memahami materi pelajaran dengan baik dalam proses pembelajaran dan tidak terjadi miskonsepsi.

Berdasarkan latar belakang yang telah disampaikan, rumusan masalah dalam penelitian ini adalah: apakah penerapan model two stay two stray berbasis eksperimen dapat meningkatkan hasil belajar daur air pada siswa kelas V SDN Tegalrejo No. 98 Surakarta Tahun Ajaran 2017/2018?. Berdasarkan rumusan tersebut maka tujuan dari penelitian ini adalah meningkatkan hasil belajar daur air dengan penerapan model two stay two stray berbasis eksperimen pada siswa kelas V SDN Tegalrejo No. 98 Surakarta Tahun Ajaran 2017/2018.

\section{METODE}

Penelitian ini merupakan penelitian tindakan kelas, sebagai rangkaian tiga siklus diterapkan dalam penelitian ini, dengan tahap perencanaan, pelaksanaan tindakan, observasi dan refleksi. Setiap siklus terdiri dari dua pertemuan. Subjek penelitian ini adalah siswa kelas 5 SD sebanyak 25 peserta didik, meliputi 17 peserta didik laki-laki dan 8 peserta didik 
perempuan, peneliti, serta guru yang menjadi wali kelas 5 SD. Data yang diambil pada penelitian ini berupa data kualitatif dan data kuantitatif yang dikumpulkan dari sumber primer yaitu siswa dan guru kelas V SDN Tegalrejo No. 98 Surakarta dan sumber sekunder yang diperoleh dari silabus, daftar nilai dan dokumentasi kegiatan pembelajaran. Teknik yang digunakan untuk mengumpulkan data diantaranya adalah wawancara yang dilakukan saat pratindakan dengan mengajukan 5 pertanyaan kepada guru dan siswa mengenai proses pembelajaran daur air, untuk menggali informasi tentang hasil belajar afektif, observasi dilakukan untuk mendapatkan hasil belajar psikomotorik, tes diujikan dengan jumlah 10 soal berbentuk pilihan ganda tentang menjelaskan, menganalisis, dan menyusun proses daur air, dan dokumentasi. Kemudian data diuji validitasnya dengan menggunakan validitas isi, triangulasi sumber dan triangulasi teknik. Teknik deskriptif komparatif digunakan untuk menganalisis data kuantitatif yang dilakukan dengan membandingkan nilai pada pratindakan, siklus pertama, siklus kedua dan siklus ketiga. Sedangkan teknik analisis data yang digunakan untuk menganalisis data kualitatif dengan model interaktif Miles dan Huberman dengan empat komponen, yaitu data collection data reduction, data display, conclusion drawing/verification.

\section{HASIL DAN PEMBAHASAN}

Berlandaskan pada analisis data penelitian tindakan kelas dengan penerapan model two stay two stray berbasis eksperimen, penelitian tindakan kelas yang dilakukan sampai dengan siklus III, menunjukkan peningkatan hasil belajar daur air siswa kelas V SDN Tegalrejo No. 98 Surakarta. Peningkatan yang terjadi dapat dilihat pada rata-rata hasil belajar ranah kognitif, afektif, dan psikomotorik, peningkatan tersebut dapat di rinci pada Tabel 1 sebagai berikut:

Tabel 1. Nilai rata-rata hasil belajar ranah kognitif, afektif, dan psikomotorik siswa kelas V SDN Tegalrejo No. 98

Berlandaskan tabel 1 dapat dilihat bahwa pada rata-rata hasil belajar kognitif saat pratindakan hanya mencapai nilai 58, 12, masih jauh di bawah KKM yang ada

\begin{tabular}{ccccc}
\hline Keterangan & $\begin{array}{c}\text { Pra } \\
\text { Tindakan }\end{array}$ & Siklus I & Siklus II & Siklus III \\
\hline Kognitif & 58,12 & 67,62 & 74,02 & 80,76 \\
Afektif & 1,04 & 1,43 & 1,82 & 2,09 \\
Psikomotorik & 1,04 & 1,53 & 1,97 & 2,32
\end{tabular}

yaitu 70. Pada siklus I, rata-rata hasil belajar kognitif meningkat mencapai nilai 67, 62, terjadi peningkatan sebanyak 9, 50. Peningkatan terjadi karena menerapkan model two stay two stray berbasis eksperimen saat pembelajaran daur air. Pada siklus II rata-rata hasil belajar kognitif meningkat mencapai nilai 74,02 , terjadi peningkatan sebanyak 6 , 40. Peningkatan terjadi karena hasil refleksi dengan memberikan siswa penjelasan secara perlahan dan lebih detail, dan memberikan motivasi kepada siswa untuk belajar lebih rajin dan memahami materi dengan perlahan ketika belajar dirumah, sehingga sampai sekolah siswa mudah mendalami materi yang sedang dipelajari. Pada siklus III rata-rata hasil belajar kognitif meningkat mencapai nilai 80,76 , terjadi peningkatan sebanyak 6, 74. Peningkatan terjadi karena hasil refleksi dengan memberikan penjelasan lebih detail, dan membimbing siswa supaya mau bertanya materi yang kurang dipahami dan memberikan motivasi kepada siswa untuk belajar lebih rajin dan memahami materi dengan perlahan ketika belajar dirumah, sehingga sampai sekolah siswa mudah mendalami materi yang sedang dipelajari. 
Dari pratindakan hingga siklus III, peningkatan yang paling besar terjadi pada saat Siklus I, peningkatan dari pratindakan ke siklus I mencapai 9, 50. Peningkatan terjadi karena dalam pembelajaran daur air menerapkan model two stay two stray berbasis eksperimen, dalam model tersebut siswa belajar secara kelompok dan melibatkan siswa dalam proses pembelajaran, siswa dapat berdiskusi dan bertukar informasi karena two stay two stray dilakukan secara bersama-sama dengan temannya baik teman satu kelompok maupun teman berbeda kelompok. Dengan berbasis eksperimen siswa dapat membuktikan kebenaran suatu teori dengan kuat, terutama IPA materi daur air, siswa dapat belajar melalui berbuat dan dapat melihat kenyataan yang asli dari suatu teori dalam materi pembelajaran, dan dapat melihat bukti yang kuat sehingga siswa dapat memahami materi pelajaran dengan baik dalam proses pembelajaran dan tidak terjadi miskonsepsi. Pembelajaran daur air dengan penerapan two stay two stray berbasis eksperimen menjadi berkesan dan materi tentang analisis dan susunan daur air dapat bertahan lama dalam ingatan siswa, dan mengingat saat pratindakan siswa belum bisa menganalisis dan menyusun proses daur air dan guru belum melaksanakan kegiatan eksperimen dan belum memanfaatkan media saat proses pembelajaran IPA, khususnya materi daur air. Peningkatan hasil belajar kognitif dalam penelitian ini sejalan dengan penelitian yang relevan milik Danang Wahyu Setiawan, yang membuktikan model two stay two stray berbasis eksperimen dapat meningkatkan pemahaman siswa, dan sesuai dengan pendapat Shoimin (2016: 225) tentang kelebihan two stay two stray yaitu kecenderungan belajar siswa menjadi lebih bermakna dan membantu meningkatkan prestasi belajar.

Rata-rata hasil belajar afektif saat pratindakan mencakup enam indikator yaitu penerimaan, respon, keaktifan, tanggung jawab, kerjasama, dan keberanian, hanya mencapai nilai 1,04, masuk ke dalam kategori cukup. Pada siklus I, rata-rata hasil belajar afektif meningkat mencapai nilai 1, 43, masuk ke dalam kategori cukup, terjadi peningkatan sebanyak 0,39 . Peningkatan terjadi karena menerapkan model two stay two stray berbasis eksperimen saat pembelajaran daur air. Pada siklus II rata-rata hasil belajar afektif meningkat mencapai nilai 1, 82, masuk ke dalam kategori cukup, terjadi peningkatan sebanyak 0, 39. Peningkatan terjadi karena hasil refleksi dengan memberikan pengutan motivasi saat siswa menjawab pertanyaan, diskusi, maupun presentasi. Pada siklus III rata-rata hasil belajar afektif meningkat mencapai nilai 2, 09, masuk ke dalam kategori tinggi, terjadi peningkatan sebanyak 0,27 . Peningkatan terjadi karena hasil refleksi dengan melakukan pendekatan kepada siswa supaya tidak membeda-bedakan teman dan memberikan pengutan motivasi saat siswa menjawab pertanyaan, diskusi, maupun presentasi.

Dari pratindakan hingga siklus III, peningkatan yang paling besar terjadi pada saat Siklus I dan II, peningkatan dari pratindakan ke siklus I dan siklus I ke siklus II mencapai 0, 39. Peningkatan terjadi karena penerapan model two stay two stray berbasis eksperimen dalam pembelajaran daur air, dan siswa diberi penguatan motivasi saat siswa menjawab pertanyaan, diskusi, maupun presentasi, karena model two stay two stray berbasis eksperimen melatih tanggung jawab dan saling membantu satu sama lain, dan siswa tidak menjadi bosan dan merasa gembira karena two stay two stray dilakukan secara bersama-sama dengan temannya baik teman satu kelompok maupun teman berbeda kelompok. Peningkatan hasil belajar afektif dalam penelitian ini sesuai dengan pendapat Shoimin (2016: 225) tentang kelebihan two stay two stray yaitu lebih berorientasi pada keaktifan, siswa akan berani mengungkapkan pendapatnya, menambah kekompakan dan rasa percaya diri siswa dan membantu meningkatkan minat belajar.

Rata-rata hasil belajar psikomotorik saat pratindakan mencakup lima indikator yaitu aktivitas melihat, berbicara, mendengarkan, menulis, dan melaksanakan eksperimen, hanya mencapai nilai 1, 04, masuk ke dalam kategori cukup. Pada siklus I, rata-rata hasil belajar psikomotorik meningkat mencapai nilai 1, 53, masuk ke dalam 
kategori cukup, terjadi peningkatan sebanyak 0, 49. Peningkatan terjadi karena menerapkan model two stay two stray berbasis eksperimen saat pembelajaran daur air. Pada siklus II rata-rata hasil belajar psikomotorik meningkat mencapai nilai 1, 97, masuk ke dalam kategori cukup, terjadi peningkatan sebanyak 0,44 . Peningkatan terjadi karena hasil refleksi dengan memberikan bimbingan kepada siswa saat berdiskusi, maupun ekperimen. Pada siklus III rata-rata hasil belajar psikomotorik meningkat mencapai nilai 2, 32, masuk ke dalam kategori tinggi, terjadi peningkatan sebanyak 0,35 . Peningkatan terjadi karena hasil refleksi dengan bimbingan yang lebih menyeluruh ke semua siswa saat proses pembelajaran baik eksperimen maupun diskusi.

Dari pratindakan hingga siklus III, peningkatan yang paling besar terjadi pada saat Siklus I, peningkatan dari pratindakan ke siklus I mencapai 0, 49. Peningkatan terjadi karena pada saat penerapan model two stay two stray berbasis eksperimen dalam pembelajaran daur air, siswa diberi bimbingan kepada siswa saat berdiskusi, maupun ekperimen, karena model two stay two stray berbasis eksperimen melakukan eksperimen dengan membuktikan suatu teori dengan kuat sehingga siswa perlu bimbingan yang lebih dari guru supaya dapat memahami materi pelajaran dengan baik dalam proses pembelajaran dan tidak terjadi miskonsepsi. Peningkatan hasil belajar psikomotorik dalam penelitian ini sesuai dengan pendapat Putra (2013: 138-139) tentang kelebihan eksperimen yaitu dalam melakukan eksperimen siswa memperoleh pengalaman dan keterampilan, siswa terampil dalam menggunakan alat percobaan, dan siswa membuat kesimpulan dengan berpikir ilmiah.

\section{SIMPULAN}

Model pembelajaran two stay two stray berbasis eksperimen dapat meningkatkan hasil belajar daur air pada siswa kelas V SDN Tegalrejo No.98 Surakarta Tahun Ajaran 2017/ 2018. Peningkatan tersebut dapat dibuktikan dengan peningkatan ketuntasan klasikal kognitif siswa sebelum tindakan hanya $32 \%$, pada siklus I 56\%, pada siklus II 76\%, dan siklus III 96\%. Sedangkan peningkatan afektif pada rata-rata nilai sebelum tindakan hanya 1,04 , berada dalam kategori cukup, pada siklus I 1, 43, berada dalam kategori cukup, pada siklus II 1, 82, berada dalam kategori cukup, dan siklus III 2, 09 berada dalam kategori tinggi. Peningkatan psikomotorik pada rata-rata nilai sebelum tindakan hanya 1,04 , berada dalam kategori cukup, pada siklus I 1, 53, berada dalam kategori cukup, pada siklus II 1, 97, berada dalam kategori cukup, dan siklus III 2, 32, berada dalam kategori tinggi. Model pembelajaran two stay two stray berbasis eksperimen merupakan pilihan yang tepat untuk materi daur air.

Saran yang dapat menjadi bahan pertimbangan yaitu: 1) Sebaiknya sekolah mengusahakan pelatihan guru dalam penerapan pembelajaran inovatif; 2) Sebaiknya guru memilih dan menerapkan model two stay two stray berbasis eksperimen, dan menggunakan media yang menarik; 3) Sebaiknya siswa lebih rajin belajar, aktif saat proses pembelajaran berlangsung, tidak malu-malu dan lebih berani mengeluarkan pendapat atau berpartisipasi; 4) Sebaiknya peneliti lebih mengkaji permasalahan tentang hasil belajar, dengan penggunaan media dan model pembelajaran yang relevan dan lebih inovatif, untuk meningkatkan hasil belajar siswa dalam mata pelajaran IPA daur air.

\section{DAFTAR PUSTAKA}

Agustiana, I G. A. T., \& I Nyoman T. (2013). Konsep Dasar IPA. Yogyakarta: Ombak

Aqib, Z. (2015). Model-Model, Media, dan Strategi Pembelajaran Kontekstual (Inovatif). Bandung: Yrama Widya. 
Aziz A., et al. (2012). Evaluation on the Effectiveness of Learning Outcomes from Students' Perspectives. Procedia - Social and Behavioral Sciences. (56), 22 30.

Gabriela, \& Paula P. (2015). Formation of some concepts of natural sciences during primary education. Procedia - Social and Behavioral Sciences. (180), 688 695.

Huda, M. (2014). Model-Model Pengajaran dan Pembelajaran. Yogyakarta: Pustaka Pelajar.

Kurniasih, I. \& Berlin, S. (2015). Ragam Pengembangan Model Pembelajaran. Jakarta: Kata Pena.

Shoimin, A. (2016). 68 Model Pembelajaran Inovatif dalam Kurikulum 2013. Yogyakarta: AR-RUZZ Media.

Sukardjo, JS. dkk. (2012). IImu Kealaman Dasar. Surakarta: UNS Press.

Tameemi, M. A., \& Vladimir, V.C. (2016). Global water cycle and solar activity variations. Journal of Atmospheric and Solar-Terrestrial Physics. (142), 55 59.

Taurina, Z. (2015). Students' Motivation and Learning Outcomes: Significant Factors in Internal Study Quality Assurance System. International Journal for CrossDisciplinary Subjects in Education (IJCDSE). 5 (4) 2625 - 2630.

Tursinawati. (2013). Analisis Kemunculan Sikap IImiah Siswa dalam Pelaksanaan Percobaan pada Pembelajaran IPA Di SDN Kota Banda Aceh. Jurnal pionir. 1 (1), 67 - 84.

Zhang, S., et al. (2017). Evaluation method for regional water cycle health based on nature-society water cycle theory. Journal of Hydrology. (551), 352 - 364. 